ORIGINAL ARTICLE

AFRICAN JOURNAL OF CLINICAL AND EXPERIMENTAL MICROBIOLOGY. MAY 2014 ISBN 1595-689X VOL15 No.2

AJCEM/1414

COPYRIGHT 2014 http://dx.doi.org/10.4314/ajcem.v15i2.6

http://www.ajol.info/journals/ajcem

AFR. J. CLN. EXPER. MICROBIOL. 15(2): 91-96

\title{
SEROLOGICAL SCREENING FOR ANTE-NATAL TOXOPLASMOSIS IN MAIDUGURI MUNICIPAL COUNCIL, BORNO STATE, NIGERIA
}

\author{
*Oyinloye, S.O1., Igila-Atsibee, M.1, Ajayi, B2., and Lawan, M.A2
}

1Department of Microbiology, Faculty of Science, University of Maiduguri, Borno, Nigeria; 2Department of Immunology, University of Maiduguri Teaching Hospital, Borno, Nigeria.

*Correspondence: faisam26@gmail.com; 08036161371

\begin{abstract}
Toxoplasma gondii infection causes devastating defects including, blindness, neurological impairment and mental retardation in congenitally infected children. Congenital infection occurs when a woman becomes infected during pregnancy; and the severity of the illness is related to the trimester period. This research was designed to evaluate the seroprevalence of toxoplasmosis amongst pregnant women $(n=90)$ using enzyme linked immunosorbent assay (ELISA) kit (Cortez Diagnostics Inc. USA). A structured questionnaire was used to collect socio-demographic data. A significant (x2 Cal 233.0/ x2 tab 124.1, $\mathrm{p}=0.01)$ overall prevalence of $22.2 \%(20 / 90)$ was obtained. Pregnant women within $25-29$ years had the highest prevalence of $33.3 \%$ (3/9); this was significant ( $\times 2$ Cal 35.85/ x2 tab 9.21, p=0.01). An association between high levels of toxoplasma IgG and miscarriage was established in four of twenty five women who had suffered miscarriage ( $t$ cal 5.3/t tab 2.81, $p=0.01$ ). The results presented indicate that toxoplasmosis is a significant public health burden in the area of study, which requires drastic remedial measures.
\end{abstract}

Key words: Toxoplasmosis, pregnant women, miscarriage, Nigeria

\section{DEPISTAGE SEROLOGIQUE POUR TOXOPLASMOSE PRENATALE DANS LA MUNIPACILITE DE MAIDUGURI, L'ETAT DE BORNO, NIGERIA}

\author{
*Oyinloye , S.O1, Igila-Atsibee, M1, Ajayi, B2Lawan, M.A2
}

1Département de Microbiologie, Faculté des Sciences, Université de Maiduguri, Borno , Nigeria; 2Département d'Immunologie, Centre Hospitalier Universitaire de Maiduguri, Borno , Nigeria .

* Adresse Mail d'auteur correspondant: faisam26@gmail.com ; 08036161371

RÉSUMÉ

L'infection de Toxoplasma gondii provoque des malformations dévastatrices, y compris, la cécité, des troubles neurologiques et un retard mental chez les enfants infectés congénitalement. L'infection congénitale se produit quand une femme est infectée au cours de la grossesse, et la gravité de la maladie est liée à la période de trimestre. Cette recherche a été conçue pour évaluer la séroprévalence de la toxoplasmose chez les femmes enceintes $(n=90)$ à l'aide de dosage immunoenzymatique (ELISA) (Cortez Diagnostics Inc. USA). Un questionnaire structuré a été utilisé pour recueillir des données socio- démographiques. Une prévalence importante globale de $22,2 \%(20 / 90)$ a été obtenu (p = $0,01)$. Les femmes enceintes dans les tranche d'âge25- 29 ans ont eu la plus forte prévalence de 33,3\% (3/9)qui était significative $(p=0,01)$. Une association entre des niveaux élevés de Toxoplasme IgG et fausse couche a été établie dans quatre des vingt-cinq femmes qui avaient subi une fausse couche $(p=0,01)$. Les résultats présentés indiquent que la toxoplasmose est un problème de santé publique dans cette localité, ce qui nécessite des mesures correctives drastiques.

Mots clés: Toxoplasmose, femmes enceintes, fausses couches, Nigeria

\section{INTRODUCTION}

Toxoplasmosis infection is caused by the parasite, Toxoplasma gondii (T. gondii), an obligate intracellular protozoan parasite found in many species of animals throughout the world and may cause a variety of clinical syndromes in

humans and animals, which leads to many serious health complications. Although 
toxoplasmosis is a cosmopolitan infection, the disease appears to be overshadowed in the tropics by other endemic diseases such as malaria and HIV (1) It has been estimated that one third of the world population has been infected by $T$. gondii (2). Transmission of T. gondii is through food-borne, with cat playing the major role of transmission (3), through faecal contamination of soil and water (4) and human acquired infection by consumption of improperly cooked meat, unpasteurized goat milk and eating unwashed fruits/vegetables (5). Infection is characterized by headache, cough, fever, body weakness, infection of the eyes, and muscle fatigue (2).

Primary infection may be mild and asymptomatic, but when transmitted transplacentally can cause congenital toxoplasmosis. Congenital toxoplasmosis leads to wide range of manifestation including mild chorioretinitis to mental retardation, microcephaly, hydrocephalus, epilepsy and seizures. It can also cause some repeated abortion, still birth and fetal loss in infected pregnant women (6).

The prevalence of toxoplasma gondii in human population varies among different countries and geographical area (7). In Asia, seroprevalence rate of $52.1 \%$ anti-toxoplasma IgG in Southern Turkey, $55.7 \%$ in Malaysia, $55.3 \%$ in India and $19.4 \%$ among Chinese population have been reported. While in Africa, 40.2\% from Senegal, $34.1 \%$ from pregnant women in Sudan (7), 63.1\% in Sao Tome and Principe (1) and 27\% in Mali (8) have been reported.

However, in Nigeria, statistics on seroprevalence of toxoplasmosis reveals $29.1 \%$ in Zaria, $26.1 \%$ in Sokoto, $44.4 \%$ in Calabar and $40.8 \%$ in Lagos (9, $5,2,6)$.

During pregnancy, the clinical implication of this infection is tremendously dangerous which necessitate the importance of evaluating the immunological status of pregnant women regarding toxoplasmosis. Yet toxoplasmosis is a neglected parasitic infection although it is extremely important economically, medically and epidemiologically (2). Compared with other parasitic infections such as malaria and filariasis, it is grossly underreported. Information on research data on toxoplasmosis in pregnant women in North East Nigeria and Maiduguri in particular is largely unavailable.

In this study, we examined the immunological status of pregnant women attending ante natal care in a secondary health facility in Maiduguri, Borno State, Nigeria.

\section{MATERIALS AND METHODS}

\section{Specimen collection}

The aim of the research was explained to antenatal attendees and there informed consent and that of the relevant hospital authority was obtained. Therefore ninety blood samples were collected from volunteer pregnant women attending antenatal care at the secondary health facility in Maiduguri, Borno State by venipuncture. Serum was obtained by centrifuging at 3000rpm for 5 minutes (9). Serum was kept frozen at $-20 \mathrm{C}$ in the Department of Immunology, University of Maiduguri Teaching Hospital until analysis was done.

\section{Specimen Analysis}

The following reagents and materials were provided preparatory for the assay: Microwell strips: purified Toxoplasma antigen coated wells (12x8wells), Sample diluents: Blue color solution $(22 \mathrm{ml})$, washing concentrate $10 \mathrm{x}$ bottles $(100 \mathrm{ml})$, TMB chromogenic substrate: Amber (12ml), Enzymes conjugate: red color solution $(12 \mathrm{ml})$, Negative calibrator: $0 \mathrm{I} \mu / \mathrm{ml}$. Natural cap (150ul/via), Cutoff calibrator: $8 \mathrm{I} \mu / \mathrm{ml}$. Yellow cap. Toxo G index=1.0 (150uI/vial) Positive calibrator: $50 \mathrm{I} / \mathrm{ml}$. (150 $\mu \mathrm{I} / \mathrm{Vial})$, Positive calibrator: $150 \mathrm{I} \mu / \mathrm{ml}$. (150 $\mu \mathrm{I} / \mathrm{vial}), \quad$ Negative

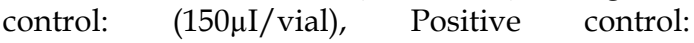

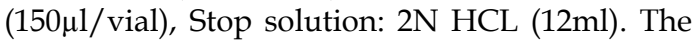
Enzyme linked immunosorbent assay technique was employed. Abiding strictly by manufacturer's instruction, one in forty (1:40) dilutions of specimen, negative control, positive control and calibrator were prepared by adding $5 \mu \mathrm{l}$ of the aforementioned to $200 \mu \mathrm{l}$ of sample diluent and mixed well. One hundred microliter $(100 \mu \mathrm{l})$ of diluted sera, calibrator and controls were dispensed into the appropriate wells. One hundred microliter $(100 \mu \mathrm{l})$ of absorbent solution was dispensed in 1A well position for the reagent blank. The holder was tapped to remove air bubbles from the liquid and was mixed well and incubated for 30 minutes at room temperature. Liquids from all wells were removed and washed three times repeatedly with washing buffer. One hundred microliter $(100 \mu l)$ of enzyme conjugate was dispensed into each well and incubated for 30 minutes at room temperature. The enzyme conjugate was then removed from all wells and washed repeatedly three times with washing buffer. One hundred microliter $(100 \mu \mathrm{l})$ of TMB Chromogenic Substrate was dispensed to each well and incubated for 15 minutes at room temperature. Then $100 \mu \mathrm{l}$ of $2 \mathrm{~N} \mathrm{HCl}$ was added 
to stop reaction. While ensuring there were no air bubbles in each well, O.D. at $450 \mathrm{~nm}$ was read with a microwell reader.

\section{Interpretation of Result}

Based on manufacturer's instruction, the mean value of Toxo- $G$ Index for each specimen was calculated by dividing the mean absorbance value of each sample by the cut off calibrator mean value. A sample was then considered positive for anti- Toxoplasma IgG antibody whenever a Toxo $\mathrm{G}$ Index value is equal or greater than $1.0(>8 \mathrm{Iu} / \mathrm{ml})$, and considered negative whenever a Toxo $G$ Index value is equal or less than $0.90(<7 \mathrm{Iu} / \mathrm{ml})$.

\section{RESULTS}

Out of 90 pregnant women screened, 20 were positive for anti-toxoplasma IgG. Therefore this gives an overall $22.2 \%$ seroprevalence (Table 1 ). We found pregnant women within 25-29 and $\geq 35$ years age bracket to have the highest prevalence of $33.3 \%$ (Table 1). Based on trimester, we found prevalence of $18.1 \%, 29.6 \%$ and $19.4 \%$ for pregnant women in first, second and third trimester respectively (Table 2). History of miscarriage shows that $16.6 \%(4 / 24)$, and $24.2 \%$ $(16 / 66)$ of pregnant women who have suffered and those who have not had miscarriage respectively were positive for anti-toxoplasma IgG (Table 3) while $33.3 \%$ and $20.9 \%$ of those who have had and those who have not had blood transfusion respectively were positive for antitoxoplasma IgG (Table 3).

TABLE 1: SEROPREVALENCE OF TOXO PLASM A GO NDII IgG IN PREGNANT WOMEN IN RELATION TO AGE

\begin{tabular}{llll} 
Age (Years) & $\mathrm{n}$ & T. gondii IgG +ve (\%) \\
\hline $15-19$ & 16 & 4 & $(25.0)$ \\
$20-24$ & 45 & 8 & $(17.7)$ \\
$25-29$ & 09 & 3 & $(33.3)^{*}$ \\
$30-34$ & 17 & 4 & $(23.5)$ \\
$\geq 35$ & 03 & 1 & $(33.3)$ \\
\hline Total & 90 & 20 & $(22.2)^{* *}$
\end{tabular}

* $\mathrm{X} 2$ cal35.85, $\mathrm{p}=0.05 ; * * \mathrm{X} 2$ cal 233.0, $\mathrm{p}=0.05$

\section{TABLE 2: SEROPREVALENCE OF TOXOPLASMA GONDII IgG IN PREGNANT WOMEN IN RELATION TO TRIMESTER}

Trimester $\mathbf{n} \quad$ T. gondii IgG positive ( $\%$ )

\begin{tabular}{lcc}
\hline First & 11 & $02(18.1)$ \\
Second & 27 & $08(29.6)$ \\
Third & 52 & $10(19.4)$ \\
\hline Total & 90 & $70(22.2)$ \\
\hline
\end{tabular}

\section{DISCUSSION}

The study showed that overall prevalence of $T$. gondii IgG antibodies in pregnant women in Maiduguri was statistically significant $22.2 \%$ (X2 cal 233.0/ X2 tab 124.0, p=0.05). This agrees with the finding of (10) who reported $22 \%$ prevalence
TABLE 3: DISTRIBUTION OF TOXO PLASM A GONDII IgG ANTIBODY IN PREGNANT WOMEN BASED ON HISTORY OF BLOOD TRANSFUSION (B/T) AND MISCARRIAGE

\begin{tabular}{|c|c|c|c|c|}
\hline \multirow{2}{*}{$\begin{array}{l}\text { T. gondii } \\
\text { IgG profile }\end{array}$} & \multicolumn{2}{|c|}{ B/T History } & \multicolumn{2}{|c|}{ Miscarriage history } \\
\hline & Yes & No & Yes & No \\
\hline $\mathbf{N}$ & 09 & 81 & 24 & 66 \\
\hline Positive & 03 & 17 & 04 & 16 \\
\hline$(\%)$ & 33.3 & 20.9 & 16.6 & 24.2 \\
\hline
\end{tabular}

among pregnant women from the Swansea area of the UK. It is however higher than 19.4\% prevalence among Chinese population (7). Comparison of the prevalence obtained in this study $(22.2 \%)$ with those of other studies in 
Nigeria show that while it is slightly lower but within the same range with prevalence from other northern states: $29.1 \%$ and $26.1 \%$ in Zaria and Sokoto respectively $(9,5)$, it is much lower than the prevalence from the southern states: $44.4 \%$ and $40.8 \%$ in Calabar and Lagos respectively $(2,6)$. This notable difference may be attributable to the extreme temperature in the north which might be inimical to the survival of the oocyst shed in the feaces of cats. The foregoing buttress the report by (11), that the distribution of this parasite depends on regions and weather condition where the oocysts survive in environment. Put together, the prevalence of Toxoplasma gondii in Nigeria could be said to have declined if the finding of (12) which reported that seroprevalence rates for pregnant women in a Nigerian population ranged from $72.5 \%$ to $88.8 \%$ with an overall rate of $75.4 \%$ is compared with seroprevalence from various states in Nigeria in recent past. This might not however portend reduction in the sequelae of the infection.

There was no definite age-related pattern of increase in seroprevalence. This is contrary to previous works which reported that seroprevalence was found to increase with age (2, 9). Pregnant women within 25-29 years group (14), vertical transmission occurs causing mental retardation, blindness, epilepsy, and death (15), and that "one of the late sequelae of congenital toxoplasmosis is chorioretinitis" (16), it therefore mean that these women are prone to the aforementioned consequences of toxoplasma infection.

We also found that all four women were in the third trimester of pregnancy which further increases the possibility of the fetuses being affected as "the risk of the infection being passed on to the fetus increases to between $60 \%$ and $90 \%$ in the third trimester" (17). Worthy of note also are fourteen (14) pregnant women who have never suffered miscarriage but were found to have high concentration of anti-toxoplasma IgG in there sera. In this case IgG-avidity index would be required to establish whether the IgG antibody indicate evidence of chronic or acute infection before allusion can be made the danger such high level of antibody portends. Should these pregnant women be proven to be undergoing acute infection, their fate would be earlier discussed.

Transmission may occur transplacentally, or through organ transplantation (18). Some animals including humans serve as intermediate had the highest prevalence of $33.3 \%$ (3/9). This was significant ( $\mathrm{x} 2 \mathrm{Cal} 35.85 / \mathrm{x} 2$ tab 9.21, $\mathrm{p}=0.01$ ). However, summing those within 20-24 years and 25-29 years together, we have the highest population of pregnant women in this study. This is indicative of the early marriageable age in the study area. This statistic which reveals the population at risk becomes significant when any remedial measure (such as health education, possible pre or ante natal screening ) to forestall the sequelae of toxoplasmosis in the study area is to be planned by relevant authority.

In this study, an association between high level (Toxo G Index > 1.5) of toxoplasma IgG and miscarriage was established in four of twenty five women who had suffered miscarriage ( $t$ cal 5.3/t tab 2.81, $\mathrm{p}=0.01$ ). Precisely, the Toxo G indices of the four pregnant women were 5.56, 5.35, 2.98 and 2.89. Since Toxo G index ratio between paired samples greater than 1.5 is highly suggestive of a significant rise in antibody and it may be considered as indicative of acute toxoplasmosis infection (13) and as it is reported that toxoplasmosis could be severe and lifethreatening during pregnancy, and to fetuses, and new born babies

hosts in which the parasite may cause systemic infection that result in the formation of tissue cysts (2). Since transmission can occur transplacentally and parasite can cause systemic infection, we posit that it might therefore not be impossible that this infection could be transmitted through blood transfusion. This because, if blood donated was "immediately" transfused to a recipient while the parasite is yet blood-borne before it establishes itself in any tissue, then it might be transmitted. Therefore in this study, we present $33.3 \%$ (3/9) seroprevalence among pregnant women who have undergone blood transfusion, although without an assessment of test of association between infection and blood transfusion. However, we recommend that these assertions be investigated in future researches.

By and large, there are factors such as level of education, rearing of cat and consumption of 'suya' that could have influenced the prevalence obtained in this study. Illiteracy is generally rampant in the study area. About $70 \%$ of those positive for anti-toxoplasma IgG in this study were illiterate. Transmission of Toxoplasma gondii is possible by containers, knives or cutting boards or other preparation surfaces contaminated with infected raw meat. This category of people might 
be less likely to wash cutting boards, knives e.t.c, with soap after cutting of raw meat due unhygienic habits. This agrees with the findings of other workers who reported that lower levels of education were associated with increased risk for toxoplasmosis (4). The culture/habit of cat rearing or cohabiting with cats in the study area may well have influenced the outcome of this work as it makes cats to come in close proximity with humans. This agrees with (19) who reported that cohabiting with cats increases the chances of getting infected. It is worthy of note to state that indigenes in the study area favoured the

\section{REFERENCES}

1. Fan C.K., Liao CW., Kao TC., Lu JL. and $\mathrm{Su}$ KE. Toxoplasma gondii infection: relationship between seroprevalence and risk factors among inhabitants in two offshore islands from Taiwan. Acta Med. 0 kayama 2001; 55:301-308.

2. Uttah EC., Ajang R., Ogbeche J., Etta H. and Etim L. Comparative Seroprevalence and Risk Factors of Toxoplasmosis among Three Subgroups in Nigeria. J. N at. Sci. Res., 2013; 1.3: 2329

3. Pezzoli 1., Marotta V., and Sattanino G. (). Toxoplasmosis in Italian women. Result of a survey on perception of food borne risk. J. fd.Print. 2009; 72:680-684.

4. Jones JL., Lopez M., Wilson J., Schulkin G. and Gubbs R. Congenital toxoplasmosis: A Review. O bs. Gyn Survey , 2001; 56: 296-305.

5. Alayande MO., Edungbola ID., Fabiyi JP., Faleke OO., Babatunde SK., Akanbi AA., and Nyamngee I. Toxoplasma gondii and intestinal helminthes infection among owned strayed cat in Sokoto, Nigeria. Res. J. V et. Sci. 2012; 5(3):69-74.

6. Akinbami AA., Adewunmi A.A., Rabiu KA., Write KO., Dosunmu AO., Dada MO. and Adeyemo TA. Seroprevalence of Toxoplasma gondii antibody amongst pregnant women at Lagos state university teaching hospital,Nigeria. Nig. Postgrad. M ed. J. 2010; 17(2): 164-7

7. Deji-Agboola AM, Busari OS., Osinupebi OA. and Amoo AOJ. The seroprevalence of Toxoplasma via antibodies among pregnant gondii research women attending ante-natal consumption of 'suya', i.e. roasted meat. This may be a veritable source of infection where the temperature of roasting is not enough to, during processing, eliminate meat parasites (20).

In conclusion, this first report on $\mathrm{T}$. gondii $\mathrm{IgG}$ immune status of pregnant women in Maiduguri shows $22.2 \%$ seroprevalence but does not indicate immunity, rather it shows that $77.8 \%$ of the population of the study area is susceptible to T. gondii infection. Comprehensive research should be conducted not only in Maiduguri but in whole of north-east region of Nigeria to ensure adequate surveillance and representative result.

clinic of federal medical centre, Lagos Nigeria. In'l Journal of Biological and M edical Science. 2011; 2(4) :1135-1139.

8. Ouologuem, D. T., Djimdé , A. A., Diallo , N., Doumbo , O. K. and Roos, D. S. (2013):Toxoplasma gondii Seroprevalence in Mali. Journal of Parasitology 99(2):371-374.

9. Ishaku, B.S., Umoh, J.U, Lawal, J. and Randawa, A.J. (2009). Seroprevalence and risk factors for Toxoplasma gondii infection among ante-natal women in Zaria, Nigeria. Research journal of medicine and medical science. 4(2):483-488.

10. Onadeko, M.O., Joynson, D.H., Payne, R.A. (1992). The prevalence of Toxoplasma infection among pregnant women in Ibadan, Nigeria. Journal of Tropical M edicine and H ygiene 95(2), 143145.

11. Dubey, J.P. and Jones J.L. (2008): Toxoplasma gondii infection in humans and animals in the United States. International Journal of Parasitology. 38, 1257-1278.

12. Onadeko, M.O., Joynson, D.H., Payne, R.A., Francis, J. (1996). The prevalence of toxoplasma antibodies in pregnant Nigerian women and the occurrence of stillbirth and congenital malformation. A frican Journal of $M$ edicine and $M$ edical Science. 25(4), 331-334.

13. Diagnostic Automation Inc., U.S.A, Calabasas, CA 91302

14. Robert-Gangneux, F., Year, H., D'Herve, D., Guiguen, C. (2009). Congenital toxoplasmosis after a preconceptional or periconceptional maternal infection. 
Pediatrics Infectious Disease Journal 28, 660-661

15. Petersen, E. (2007): Toxoplasmosis. Semin Fetal Neonatal M edicine, 12, 214223.

16. Al-Azawi, A.K.A., Al-Rawe, I.H.A., and Al- Bayati, R.Y.J. (2013). Seroprevalance of toxoplasmic chorioretinitis in Baghdad Province. International Journal of Science and Nature 4(1), 68-71.

17. Tenter, A.M., Heckeroth, A.R., and Weiss, L.M. (2007). Toxoplasma gondii: from animals to humans. International Journal of Parasitology 30, 1217-1258

18. Nissapatorn, V., Leong, T.H., Lee, R., Init-Ithoi, Ibrahim, J., and Yen, T.S. (2011). Seroepidemiology of toxoplasmosis in renal patients. Southeast A sian Journal of Tropical M edicine and Public Health 42 (2), 237247.

19. Sukthana, Y., Chintana, T., Damrongkitchaiporn, S., Lekkla, A. (2001). Serological study of Toxoplasma gondii in kidney recipients. Journal of M edical Association of Thailand 84, 11371141.

20. Faleke O.O., Ogundipe G.A.T. (2003). Some risk factors for Taenia saginata cysticercosis in a northwestern state of Nigeria. Nigerian Veterinary Journal 24(3): 65-71. 